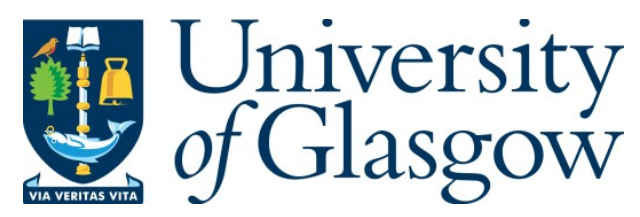

Scott, P. F. (2016) An inherent jurisdiction to protect the public interest: from PII to 'secret trials'. King's Law Journal, 27(2), pp. 259-275.

There may be differences between this version and the published version. You are advised to consult the publisher's version if you wish to cite from it.

http://eprints.gla.ac.uk/124315/

Deposited on: 16 September 2016

Enlighten - Research publications by members of the University of Glasgow http://eprints.gla.ac.uk 


\section{An inherent jurisdiction to protect the public interest: from PII to 'secret trials'}

\section{INTRODUCTION}

The law of public interest immunity (PII), which permits the non-disclosure of material in evidence where its disclosure would harm the public interest, is well known to public lawyers. A series of cases on the topic of 'secret trials' - criminal trials held wholly or in part in camera so as ensure the non-disclosure to the public of sensitive information which might otherwise emerge as part of the trial process - shows, however, that the law of public interest immunity should not be understood as a wholly sui generis body of law. Instead it is only one of what is potentially a range of tools possessed by the courts which have in common the end to which they are oriented (the protection of the public interest against disclosure of sensitive information), the mechanism by which they are prompted (a Ministerial certificate stating that the public interest requires that certain information not become known to the public at large), and the legal authority by which they take place (the inherent jurisdiction of the courts). This paper in its first part defends that claim by reference to the relevant case law, outlining the law of PII (particularly as it relates to criminal trials) and the emergence alongside it of a body of case law on in camera trials which has at times struggled to differentiate itself from that on PII. By way of explaining that struggle, it explores the commonalities which exist between the two phenomena and argues that to emphasise these commonalities has contributed - and will further contribute in future - to the task of imposing upon the use of in camera trials the sorts of limits which have over time developed to restrict the use of PII. The paper's second part considers the distinctions between the two mechanisms in terms of the circumstances in which they will be requested and the interaction between them, showing how the emergence of the in camera order alongside the better-known law of PII could make possible prosecutions which would otherwise be abandoned. The third section considers a second set of differences between the two, centred around each's 
relationship with the constitutional principles of open and natural justice, and explains how that difference manifests itself in more restrictive criteria for the making of an in camera order than for the grant of PII. Finally, it examines the judicial belief, upon which the possibility of using the inherent jurisdiction to these ends is predicated, that neither of the procedural mechanisms are per se incompatible with the principle of natural justice.

\section{PUBLIC INTEREST IMMUNITY AND 'SECRET TRIALS'}

Though it enjoys some (rather oblique) statutory recognition, ${ }^{1}$ the modern law of public interest immunity is to be found in large part in the decision of the House of Lords in Wiley. ${ }^{2}$ Therein, PII is described by Lord Templeman as "a ground for refusing to disclose a document which is relevant and material to the determination of issues involved in civil or criminal proceedings". 3 More recently, Lord Clarke in $A l$ Rawi described the principles of PII as "a construct of the common law which were developed because it was appreciated that conflict may arise between the public interest and established rules of discovery and disclosure." ${ }^{4}$ It arises where it is claimed that the public interest in non-disclosure of certain documents (for reason of the sensitivity of their contents) outweighs the public interest in their disclosure (which can generally be understood as consisting in the contribution such disclosure will make to the fair and effective administration of justice). As reflected in the label - 'Crown privilege' - by which the phenomenon was originally known, it was previously believed that the Crown alone enjoyed the right to make a claim for non-disclosure. ${ }^{5}$ It is clear, however, that claims of PII need not be made by a governmental actor, ${ }^{6}$ nor even, it would seem, by a party to the action in relation to

\footnotetext{
${ }^{1}$ See eg Crown Proceedings Act 1947 s 28; Criminal Procedure and investigations Act 1996 s 3(6).

${ }^{2} \mathrm{R} v$ Chief Constable of West Midlands Police, ex parte Wiley [1995] 1 AC 274.

3 [1995] 1 AC 274, 280.

${ }^{4}$ Al Rawi v Security Services [2011] UKSC 34; [2012] 1 AC 531, [140].

${ }^{5}$ For a brief overview of the history of PII, see Simon Brown, 'Public Interest Immunity' [1994] Public

Law 579.

${ }^{6} D v$ National Society for the Prevention of Cruelty to Children [1978] AC 171.
} 
which disclosure is being considered: in $\mathrm{R} v$ Lewes Justices, ex parte Secretary of State for the Home Department, Lord Reid asserted that "it must always be open to any person interested to raise the question and there may be cases where the trial judge should himself raise the question if no one else has done so". ${ }^{7}$ Further, the use of the language of privilege in this context is now deprecated given that, where the criteria of PII are met, the material in question cannot be disclosed even if the parties to an action are willing to see it made public. Unlike those legal privileges which are properly so called, PII protects the interest of the public as a whole and so cannot be waived. ${ }^{8}$

Claims for PII which are made by the Crown and other organs of the state (the majority, one must assume) are at least some of the time - and perhaps most of it - underpinned by a document, laid before the court, which asserts that, with regard to the particular material to which it relates, the balance of the competing public interests in disclosure and non-disclosure falls on the side of non-disclosure. Such document is usually described as a 'PII certificate'." Where previously a certificate of this sort would be treated as dispositive of the question of what the public interest required, ${ }^{10}$ the law as it now stands requires that the court satisfy itself that the balance between the competing public interests at stake is as the certificate claims it to be. ${ }^{11}$ If the court disagrees, the material must be disclosed (or, if the party in possession of that material is unwilling to disclose it, that party must, it seems, concede the aspect of the litigation to which

\footnotetext{
${ }^{7} \mathrm{R} v$ Lewes Justices, ex parte Secretary of State for the Home Department [1973] AC 388, 400.

8 "It is an axiom of the law of discovery that documents may be protected from production by reasons of state. This was formerly known as Crown privilege but that name is now out of fashion because it is not a matter of privilege and it is not confined to the Crown." Buttes Gas and Oil Cov Hammer (No 3) [1981] QB 223, 262 per Brightman J.

${ }^{9}$ R (FI) v Secretary of State for the Home Department [2014] EWCA Civ 1272; [2014] HRLR 30 provides recent confirmation that it is possible for PII to be upheld in the absence of such a certificate.

${ }^{10}$ Duncan v Cammell Laird [1942] AC 624. The correctness of that decision must be doubted. For a trenchant critique see D H Clark, A'dministrative Control of Judicial Action: The Authority of Duncan v Cammell Laird' (1967) 30 Modern Law Review 289.

${ }^{11}$ Conway v Rimmer [1968] AC 910. In Scots law the reversal was effected earlier, in Glasgow Corporation v Central Land Board 1956 SC (HL) 1.
} 
the material relates). ${ }^{12}$ Where material is not disclosed because it is material in respect of which PII has been successfully claimed, it cannot be relied upon by any party to the proceedings. ${ }^{13}$ This can happen, it seems, even where it would have the effect of rendering an action untriable and therefore lead to the court striking out the claim in question. ${ }^{14}$

In retaining an equality of arms as between the parties to an action PII differs in a key way from the more modern phenomenon of the 'closed material procedure' (CMP), in which material can be relied upon by the court notwithstanding that it has not been disclosed to one of the two parties and that party's legal team, but only to a special advocate appointed specifically for that reason. ${ }^{15}$ This significance of this difference is that, where PII is capable of being employed compatibly with the principle of natural, CMP by definition involves a departure from it. This in turn explains why CMP, unlike PII, can take place only where statutory authority is present. ${ }^{16}$ The use of PII to justify non-disclosure of material in evidence, though in the past the source of public attention and significant controversy, ${ }^{17}$ would seem to be relatively routine, though no figures are kept which would allow that impression to be confirmed or dispelled. ${ }^{18}$

\footnotetext{
12 Al Rawi [2011] UKSC 34, [145] per Lord Clarke. Lord Clarke cites to the dicta of Lord Hoffman in Secretary of State for the Home Department v MB [2007] UKHL 46; [2008] 1 AC 440, [51], though it is not clear that the paragraph to which reference is made provides clear authority for the statement in question. 13 Al Rawi [2011] UKSC 34, [41] per Lord Dyson.

${ }^{14}$ Carnduff v Rock [2001] EWCA Civ 680; [2001] 1 WLR 1786. The decision of the Court of Appeal in Carnduff has been much criticised: see Adrian Zuckerman, 'Closed material procedure - denial of natural justice: Al Rawi v 'The Security Service' [2011] UKSC 34 (2011) Civil Justice Quarterly 345, 353 and Adam Tomkins, 'Justice and Security in the United Kingdom' (2014) 47 Israel Law Review 305, 320.

15 Tomkins (n 14) 310-11.

${ }^{16}$ Al Rawi [2011] UKSC 34. That the statutory authority in question need not be particularly explicit is demonstrated by Bank. Mellat v Her Majesty's Treasury (No. 1) [2013] UKSC 38; [2014] AC 700.

${ }^{17}$ The most important example in this context is the invocation of PII in relation to the abortive Matrix Churchill trial: see Anthony Bradley, 'Justice, Good Government and Public Interest Immunity' [1992] Public Law 514, Gabriele Ganz, 'Matrix Churchill and Public Interest Immunity' (1993) 56 Modern Law Review 564; Adam Tomkins, 'Public Interest Immunity after Matrix Churchill' [1993] Public Law 650; T.R.S. Allan, 'Public interest immunity and ministers' responsibilities' [1993] Criminal Law Review 660. These issues were considered by the Scott Report: see, most importantly, The Right Honourable Sir Richard Scott, Report of the Inquiry into the Export of Defence Equipment and Dual-Use Goods to Iraq and Related Prosecutions, HC 115 (1995-96), G18.43-106.
}

18 Tomkins (n 14) 308. 
Where CMP has not been made available within the criminal justice system, PII claims can be and frequently are made in that context. ${ }^{19}$ The invocation of PII in relation to criminal proceedings, evidenced in cases going back more than a century, ${ }^{20}$ gives rise to certain considerations over and above its application in the civil sphere, from which most of the PII case law derives. ${ }^{21}$ Prominent amongst these was the disputed question of whether it was possible to make a 'class' claim for PII - that is, one based not upon the contents of the specific documents to which the claim related but on the class of documents to which those documents belonged - in relation to criminal trials. This question no longer arises, as the practice was abandoned (generally, rather than merely in relation to criminal trials) following criticism by Lord Scott in his report on matters arising out of the Matrix Churchill affair. ${ }^{22}$ Now, PII in criminal trials is governed in the first place by the Criminal Proceedings and Evidence Act 1996, section 3 of which places the prosecution under a general duty of disclosure, ${ }^{23}$ but makes that duty subject to the exception that " $[\mathrm{m}]$ aterial must not be disclosed under this section to the extent that the court, on an application by the prosecutor, concludes it is not in the public interest to disclose it and orders accordingly." 24 The possibility of non-disclosure is though limited by the requirement that the process viewed as a whole must not be unfair to the defendant. If that would be the effect of material's non-disclosure, then "fuller disclosure should be ordered even if this leads or may lead the prosecution to discontinue the proceedings so as to avoid having to make

\footnotetext{
${ }^{19}$ The decision of the House of Lords in $\mathrm{R} v H$ [2004] UKHL 3; [2004] 2 AC 134 provides authoritative guidance as to the limits of PII claims in the criminal context and their interaction with the rules of disclosure.

${ }^{20}$ See eg Marks v Beyfus (1890) 25 QBD 494. This use can in turn be traced back, albeit in a rather different and rather less certain form, to the judgments in the treasons trials of 1794: see R v Hardy (1794) 24 St Tr 199.

${ }^{21}$ The reason for this, according to Lord Bingham, is that until the 1990s "disclosure [in criminal cases] was left largely to the judgment of the prosecuting authorities and the prosecution, and only exceptionally did the court make any ruling." $\mathrm{R} v H$ [2004] UKHL 3, [19].

${ }^{22} \mathrm{~S} \operatorname{cott}(\mathrm{n}$ 17).

${ }^{23}$ As amended, s 3(1) requires that the prosecutor disclose "any prosecution material which has not previously been disclosed to the accused and which might reasonably be considered capable of undermining the case for the prosecution against the accused or of assisting the case for the accused."

${ }^{24}$ Criminal Proceedings and Evidence Act 1996 s 3(6).
} 
disclosure." ${ }^{25}$ As such, while the issue of unfairness arising out of the use of PII in civil cases remains contentious, ${ }^{26}$ its use in the criminal context is clearly bounded by a requirement that fairness be preserved. ${ }^{27}$ Why this distinction (if that is what it is) might exist is not difficult to surmise: criminal trials implicate the liberty of the individual in a way which civil procedures do so only contingently, ${ }^{28}$ and the use of PII to justify non-disclosure in evidence of material without which a criminal cannot take place fairly is liable to result in a miscarriage of justice.

Alongside PII a second exception to the ordinary procedural rules of the criminal courts must now be numbered: the holding of trials wholly or partially in camera, with press and public excluded. An examination of recent cases in which trials have taken place in camera suggests that there exist important continuities between this phenomenon and that of PII, such that the two mechanisms have been treated as analogous one to the other (as is, on the present account, legitimate) and at times even, as will be seen, discussed as though they were the same thing (which is not). Four examples fall to be considered here. The first can be dealt with briefly, for it discloses relatively little about the relevant legal issues. In April 2007, 6 individuals were convicted of offences contrary to the Explosive Substances Act 1883 and (in the case of 2 of the 6) offences contrary to the Terrorism Act 2000. The decision of the Court of Appeal Criminal Division $^{29}$ in the (unsuccessful) appeal against the convictions makes clear that the trial took place partly in camera in order to consider material relating to the alleged mistreatment in Pakistan of Salahuddin Amin, one of the 6 defendants, and the circumstances of his arrival in

\footnotetext{
${ }^{25} \mathrm{R} v \mathrm{H}$ [2004] UKHL 3, [36].

${ }^{26}$ For a recent critique of the view taken by the courts on this point, see David Heaton, 'Carnduff, $\mathrm{Al}$ Rawi, the "unfairness" of public interest immunity and sharp procedure' (2015) Civil Justice Quarterly 191.

${ }^{27}$ The government has long accepted that it is inappropriate to claim PII in relation to material which is required for defence against a criminal charge: see the statement of the Lord Chancellor, Viscount Kilmuir at HL Deb 06 June 1956 vol 197, col 745.

${ }^{28}$ It was noted by Viscount Simon in a leading case that "The judgment of the house in the present case is limited to civil actions and the practice, as applied in criminal trials where an individual's life or liberty may be at stake, is not necessarily the same." Duncan v Cammell Laird [1942] AC 624, 633-4.

${ }^{29} \mathrm{R} v$ Khyam [2008] EWCA Crim 1612
} 
Britain. ${ }^{30}$ Amin has since brought civil claims against the Director General of the Security Service and others on the basis that British intelligence officers were complicit in his mistreatment in Pakistan. These claims (which have been struck out as an abuse of process, in that they attempt to re-open issues of fact which had been decided by the trial judge ${ }^{31}$ repeatedly assert that the in camera order was made in light of ${ }^{32}$ or 'following consideration of ${ }^{33}$ a PII Certificate, indicating either a belief in the existence of a continuity between the two phenomena or, alternatively, a failure to distinguish carefully between them. Contributing to the confusion is the fact that alongside the in camera regime in Amin a traditional PII process (that is, one resulting in material's non-disclosure rather than its disclosure in camera) seems also to have taken place ${ }^{34}-$ indeed, and foreshadowing a discussion which will take place below, some material seems to have been disclosed only because it would only be aired in camera. ${ }^{35}$ The basic point is not, however, further explored in the various civil judgments and nothing in the available criminal judgments sheds light of what relationship - if any - the judge who made the original in camera order took to exist between that order and the law of PII.

More light is shed on the subject by a second case, exparte $A,{ }^{36}$ where an individual was being tried for conspiracy to cause explosions in the United Kingdom. Like Amin, he had been arrested on an inbound flight from Pakistan where he had been, for the previous ten months, detained. He claimed that during that detention he had been "tortured mentally and physically

\footnotetext{
${ }^{30}$ [2008] EWCA Crim 1612, [47]-[52]. The in camera regime was subject to an unsuccessful interlocutory appeal.

31 See most recently Amin v Director General of the Security Service [2015] EWCA Civ 653. For the rule against this use of civil proceedings, see Hunter v Chief Constable of West Midlands Police [1982] AC 529.

32 Amin v Director General of the Security Service [2015] EWCA Civ 654, [3].

33 Amin v Director General of the Security Service [2014] EWCA Civ 598, [10]. Intriguingly, we are told that the regime was put in place "following consideration of, amongst other things, a PII certificate." (emphasis added). What those others things might be is unclear.

${ }^{34}$ See, eg, R v Khyam [2008] EWCA Crim 1612, [52].

35 ibid.

${ }^{36} \mathrm{R} v$ The Crown Court at the Central Criminal Court, ex parte. A [2006] EWCA Crim 4.
} 
and subjected to interrogation by British, American and Pakistani intelligence authorities". ${ }^{37}$ The trial judge, on application by the Crown, made an order requiring that the parts of the trial which dealt with these claims be heard in camera, because "general publication of the relevant parts of it could give rise to a substantial risk to national security. Additionally it could obstruct the identification of, and cause the Crown to be deterred from prosecuting in this and other cases, those who it is in the public interest should be tried..." ${ }^{38}$ Disclosure would be contrary to the public interest; an in camera order was the appropriate way of preventing that disclosure. The defendant, along with various media organisations, appealed against the order. Counsel for one such organisation argued that certain of the material upon which the trial judge based his order should have been disclosed to the media. The Court of Appeal demurred, and it was in the context of its rejection of that submission that it contextualised the order in relation to the law of PII:

When an application for an in camera hearing is being made, it is self-evident that if it is to be justified on the grounds of national security, or the protection of the identity of witnesses, some at least of that material is almost certainly bound to be highly sensitive, and cannot be made available for dissemination. The judge must examine the material and decide whether or not the application is justified. If counsel representing media interests are put into possession of the same material as the judge before he makes his decision, the purpose of an in camera hearing would be defeated... The same practical considerations apply to the more familiar application for public interest immunity. If the desired confidentiality is broken in advance of the hearing, there is no confidentiality to be preserved. ${ }^{39}$

\footnotetext{
37 ex parte $A$ [2006] EWCA Crim 4. [2].

38 ex parte $A$ [2006] EWCA Crim 4, [7] quoting the reasons given for the making of an order dated 28 November 2005.

39 exparte $A$ [2006] EWCA Crim 4, [20].
} 
Though the penultimate sentence is perhaps ambiguous, such that it is unclear whether the Court of Appeal is referring here to a PII application made in the case or merely referring in the abstract to a process which is more familiar than is that under discussion, two things seem clear. First, that an opposition is recognised between the application for an in camera trial and one, actual or hypothetical, for PII. Second, that - as the Amin case might also be taken to suggest there nevertheless exists a continuity between the two mechanisms: them being aimed at essentially the same end (the non-disclosure of sensitive information), it is both legitimate and in fact logically necessary to read over procedural practice from the one context to the other. The defendants were convicted and appealed unsuccessfully against the conviction. ${ }^{40}$

The suggested continuity is evidenced further by events of summer 2014, when the issue of in camera trials resurfaced as the trial of two individuals alleged to have committed various terrorism related offences was ordered to take place who (rather than merely in part) in camera and with the defendants anonymised. When it gave judgment, the Court of Appeal - varying the order so as to allow the defendants to be named and to permit specific elements of the trial to take place in open court - noted that the Crown's application for an in camera trial was:

supported by Certificates ... setting out the reasons relied on in support, signed by the Secretary of State for the Home Department ... and the Secretary of State for Foreign and Commonwealth Affairs... ${ }^{41}$

Though a proportion of Ministerial certificates have a statutory basis, ${ }^{42}$ these particular certificates seem not to fulfil any statutory function. Instead, they would appear to be functionally equivalent to those which are familiar from the context of PII, in which the

\footnotetext{
40 Abmed v R [2011] EWCA Crim 184.

${ }^{41}$ Guardian News and Media Ltd v Incedal [2014] EWCA Crim 1861; [2015] 1 Cr. App. R. 4, [4].

${ }^{42}$ See eg Inquiries Act 2005 s 36.
} 
certificate serves to give the courts notice of the executive's assessment as to where the balance of the public interest lies in relation to the disclosure particular information and, in turn, asserts the necessity of preventing that disclosure. Unlike in the context of PII, these certificates lead to disclosure to the public at large being prevented not by the non-disclosure of certain material in evidence, but with disclosing it before a court from whose proceedings press and public are excluded.

The extent of the continuity between the two phenomena is demonstrated in particular by the court's willingness to rely on not just the practical considerations familiar from PII, but on the jurisprudence specific to that context. Where it notes that "the question of whether to give effect to a Ministerial Certificate (asserting, for instance, the need for privacy) such as those relied upon by the Crown here is ultimately for the Court, not a Minister. However, in the field of national security, a Court will not lightly depart from the assessment made by a Minister," ${ }^{43}$ it cites in support of this final proposition Secretary of State for Foreign and Commonwealth Affairs v Assistant Deputy Coroner for Inner North London, ${ }^{44}$ in which the relevant certificates were indeed PII certificates, asserting the need for non-disclosure of documents of relevance to the issues arising from the inquest into the death of Russian dissident Alexander Litvinenko. There is a direct transposition of jurisprudence from one context to the other and to that extent Incedal goes a step further than do the (unglossed and at times ambiguous) references to PII in the earlier in camera cases, even while the court here is careful to refer to the certificates underlying the in camera order in terms which implicitly acknowledge that the two mechanisms are not one.

Late 2014 saw too the return to the courts of issues arising out of the third example of a criminal trial taking place in camera. In January 2008 it was ordered that the trial of Chinese dissident

\footnotetext{
${ }^{43}$ Incedal [2014] EWCA Crim 1861, [19].

${ }^{44}$ Secretary of State for Foreign and Commonwealth Affairs v Assistant Deputy Coroner for Inner North London [2013] EWHC 3724 (Admin); [2014] ACD 43.
} 
Wang Yam for the murder of retired writer Allan Chappelow take place partially behind closed doors. ${ }^{45}$ The defendant was eventually convicted after a retrial and unsuccessfully appealed that conviction. ${ }^{46}$ In late 2013, having made an application to the European Court of Human Rights challenging his conviction on Article 6 grounds, Wang Yam sought to confirm that the original order did not prevent reference being made to the 'in camera material' before that Court; if it did, he sought to have it varied so as to permit such reference. Earlier judgments relating to the challenge to the in camera order on one hand and the conviction on the other, both of which predate Incedal by several years, do not make any reference to either PII or certificates of any kind, ${ }^{47}$ though media reports at the time of the trial indicated that a PII certificate had been signed by the then Home Secretary, Jacqui Smith. ${ }^{48}$ With variation of the in camera order having been sought in 2014, however, counsel for Attorney General "produced a Public Interest Immunity Certificate, signed by the Secretary of State for Foreign Affairs and dated 11 December 2013, confirming the continuing public interest which underlay the 'in camera' order in the first place". ${ }^{49}$ That certificate, as quoted by the judge to whom the application for variation of the order was made, stated that "there would be a real risk of serious harm to an important public interest were either the Order to be discharged in its entirety, or in part, permitting disclosure of the 'in camera' information" or the response that counsel for Wang Yam had prepared to the UK government's observations on his application. ${ }^{50}$ The judge's acceptance of the certificate's contents was largely dispositive of the issues before him:

I accept what the PII Certificate says. The Certificate makes it clear that the circumstances which persuaded me and the CACD in 2008 of the need for parts of the

\footnotetext{
${ }^{45}$ See $R v$ Wang Yam [2008] EWCA Crim 269, in which the Criminal Division of the Court of Appeal dismissed a challenge to the order in question.

46 Wang Yam v R [2010] EWCA Crim 2072.

${ }^{47}$ R v Yam [2008] EWCA Crim 269; Yam v R [2010] EWCA Crim 2072.

${ }^{48}$ Frances Gibb, Why is Home Office trying to stage murder trial in secret?, The Times (December 13 2007).

${ }^{49}$ Wang Yam v HM Attorney General [2014] EW Misc 10 (CCrimC), [5].

50 [2014] EW Misc 10 (CCrimC), [5].
} 
evidence not to be available to the public and press continue unchanged. Indeed, that was not at issue before me. The closed Schedule to the Certificate also explains clearly why that material should not be made available to the Strasbourg Court, whether or not it uses its procedural powers to impose restrictions on the availability of the material to the public or press. ${ }^{51}$

The judge therefore refused to vary the order in the manner desired, and in fact varied it so as to make clear that it prevented the disclosure of the material in question to the staff and members of the Court of Human Rights. ${ }^{52}$ An application for judicial review of that decision was later dismissed, ${ }^{53}$ and an appeal against that dismissal was rejected by the Supreme Court in late $2015 .^{54}$

This subsequent litigation neatly illustrates an important secondary element of the use of in camera orders. Such orders have - as discussed below - usually been made in relation to material of which the defendant is already aware (and which he in fact wishes to rely upon by way of defence) and of which in any event the in camera process (where the public and press are excluded, but the defendant is not) does not prevent him becoming aware. This means that an in camera order must - if its effect is not to be negated - continue to regulate what the defendant does with the material in question even after conviction or acquittal, in a way which PII (which will often relate to material of which the defendant is not aware and of which he will not, where the PII claim is successful, become aware) need not usually do. In Wang Yam, as the above shows, that might prevent a defendant from putting the relevant material before the Strasbourg court (it must be assumed, by analogy with Bank Mellat (No 1), ${ }^{55}$ that no in camera order could prevent a

\footnotetext{
51 [2014] EW Misc 10 (CCrimC), [50].

52 [2014] EW Misc 10 (CCrimC), [71].

${ }_{53} \mathrm{R}$ (Wang Yam) v Central Criminal Court and the Attorney General [2014] EWHC 3558 (Admin).

${ }^{54} \mathrm{R}$ (Wang Yam) v Central Criminal Court [2015] UKSC 76.

${ }^{55}$ Bank Mellat v HM Treasury (No 1) [2013] UKSC 38.
} 
domestic court from reviewing the material in question where to do so was necessary for justice to be done). In the case of Amin, the ongoing effect of the original in camera order has been to require that subsequent civil hearings take place in private and that subsequent judgements both civil and criminal - are heavily redacted. ${ }^{56}$

In the Wang Yam case, the continuity between the two procedural mechanisms which serve to protect the public interest - PII and in camera orders - seems to go further than was the case in the examples of ex parte $A$ and Incedal. Rather than merely analogising between the two, or drawing on the PII case law to influence the procedure according to which an in camera order is made Ouseley J implicitly assimilates them by labelling - as was done (albeit retrospectively) in Amin - a ministerial certificate which asserts the need for a trial to be held in camera a 'PII certificate'. Quite apart from the fact that, as the Amin case suggests, PII and in camera processes may well take place in conjunction with each other (and, indeed, a single Ministerial certificate might simultaneously assert the necessity of each) such verbal conflation is readily explicable for, we can now see, the two mechanism are similar in a number of significant ways. First, and most fundamentally, the in camera order is - like PII - a method by the courts are able to protect the public interest against the harm which would otherwise be caused by the disclosure of certain information as part of the legal process. Second, and again like PII, the making of an in camera order will, it seems, often - perhaps always - be prompted by a Ministerial certificate which communicates to the courts the executive's belief that the balance of the public interest requires the procedural mechanism to be employed. Such certificates were, as we have seen, mentioned in both the Amin case and in exparte $\mathrm{A}$ as motivating the making of an in camera order.

\footnotetext{
${ }^{56}$ The most important examples are the criminal appeal $\mathrm{R} v$ Khyam [2008] EWCA Crim 1612 and, on the civil side, Amin v Director General of the Security Service [2013] EWHC 1579 (QB) (the High Court's judgment on an application to strike out the Particulars of Claim in the civil action) in which entire paragraphs are redacted. The link between the in camera regime and later redactions is stated in Amin v Director General of the Security Service [2014] EWCA Civ 598, [10].
} 
Given that the two mechanisms share these fundamentals there is, on both points, a compelling logic for transposing to the context of in camera trials both the substantive law and the procedural practice which has developed in the context of PII. The benefits of doing so can be demonstrated briefly by reference to one of the ways in which the practice of making an in camera order has implicitly adopted the current, rather than past, practice of PII. It was noted above that for much of the twentieth century the courts responded to the executive's assessment that the balance of the public interest required PII to be granted by simply nodding along to that assessment. Only with the decision in Conway $v$ Rimmer ${ }^{57}$ did the courts assume for themselves the right to review the government's assessment of what the public interest required and so potentially - to disagree with the executive's position as to where the balance between the public interest in disclosure and that in non-disclosure lay. It seems clear that, by implicit analogy with PII, the courts have taken the same approach to the making an in camera order: it is ultimately for them, and not the executive, to decide whether or not the balance of the public interest requires such a thing. This is an unambiguous good - not only substantively, but also because it shows how the recognition of a continuity between PII and in camera trials leads the courts to apply to the latter the limitations they have developed in the context of the former rather than developing new, and potentially weaker, procedural protections. While the courts may have sometimes failed to adequately distinguish the two mechanisms, this is a significantly lesser failing than would be their artificial separation and the consequent development of weaker procedural protections in relation to in camera trials than have been developed over time for the use of PII.

A final point about the commonalities between PII and in camera trials: the two mechanisms are linked not only by their aim and the circumstances which will prompt their use, but also by the fact that each represents an exercise of the same legal power. That is, when a judge accepts a

${ }^{57}[1968]$ AC 910. 
claim of PII, and therefore permits the non-disclosure of sensitive material in evidence with a view to the protection of the public interest, the power which he exercises is not in any sense conferred on him by the principles of PII, which instead determine how and when that power can and should be exercised (as well as, conversely, when it cannot). The point has been made by the Supreme Court that when the courts developed the principles of PII, they were exercising their "inherent power in controlling [their] own procedures by deciding the scope of disclosure in cases involving confidential material." 58 Though statute may recognise the possibility of PII being claimed, no statute creates that possibility. Similarly, in the in camera cases, the courts seem to be of the opinion that the orders being made are made under the inherent jurisdiction which the courts enjoy by virtue of their status as courts rather than on the basis of any statutory or other authority. The point is addressed directly only in Wang Yam, where it was held that though the jurisdiction is acknowledged in the Criminal Procedure Rules, it derives neither from either those Rules, nor from the Official Secrets Act $1920 .{ }^{59}$ Instead, said the Lord Chief Justice, "Ouseley J rightly held in his public judgment that he had an inherent power to exclude the press and the public where the interests of justice required it". ${ }^{60}$ The reference to the 1920 Act is a reference to the provision in that statue which permits the prosecution to apply, in the course of proceedings under the Act or its 1913 counterpart to have the public excluded from the hearing where "the publication of any evidence to be given or of any statement to be made in the course of the proceedings would be prejudicial to the national safety" ${ }^{\prime 1}$ Other statutory provisions

\footnotetext{
58 Al Rawi [2011] UKSC 34, [20].

${ }^{59} \mathrm{R} v$ Wang Yam [2008] EWCA Crim 269, [5]-[6]. The relevant provisions of the Criminal Procedure Rules are now Rules 16.1, which acknowledges the inherent jurisdiction to hold a trial in private on national security grounds, and 16.6-16.8, which govern the procedure which must be followed where the court can order a trial take place in private. Other statutory provisions which permit the courts to restrict access to the courtroom are s 37 of the Children and Young Persons Act 1933, as amended, which applies where the court receives evidence from a person under 18, and s 75 of the Serious Organised Crime and Police Act 2005, which applies where the court is reviewing a sentence passed on a defendant who has assisted an investigation.

${ }^{60} \mathrm{R} v$ Wang Yam [2008] EWCA Crim 269, [5]-[6].

${ }^{61}$ Official Secrets Act $1913 \mathrm{~s}$ 8(4). The power is expressly stated to be "without prejudice to any powers which the court may possess to order the exclusion of the public from any proceedings". It does not extend to the passing of any sentence, which must take place in public.
} 
recognise, without themselves creating, a power to exclude the public: the Administration of Justice Act 1960 exempts, from the general rule that it is not a contempt of court to publish information relating to proceedings before a court sitting in private, those situations in which "the court sits in private for reasons of national security during that part of the proceedings about which the information in question is published." ${ }^{\prime 2}$ The significance of the decision in $W$ ang Yam, however, is to confirm that these statutory creations and recognitions of a power to hold an in camera trial are of no direct relevance to the phenomenon described here, which is instead explicitly based upon the inherent jurisdiction of the courts and which lacks the limits imposed by the formulation of any actual or hypothetical statutory authorisation for ordering such a trial. ${ }^{63}$ This jurisdiction has itself been stated to be a feature of neither statute nor common law; it derives instead "from the very nature of the court as a court of law" ${ }^{64}$ and has as its key feature that it "is exercisable as part of the administration of justice. It is part of procedural law, both civil and criminal, and not of substantive law; it is invoked in relation to the process of litigation" ${ }^{65}$ Not only, therefore, do the different procedural mechanisms at issue have the same broad objective - they seek in their own ways to protect the public interest against the harm that would be caused by the disclosure of sensitive information - but they also represent exercises of the same underlying legal authority. They are both examples of the courts using their inherent jurisdiction in a manner calculated to protect the public interest against the disclosure of sensitive material.

III. Degrees of sensitivity: the coexistence of PII and 'secret trials'

\footnotetext{
${ }^{62}$ Administration of Justice Act 1960 s 12(1)(c).

${ }^{63}$ The inherent jurisdiction extends to making those orders deemed necessary to ensure the effectiveness of the exclusionary order, including one which places restrictions on the reporting of the material revealed in camera which are broader than any statutory power would seem to permit: see $R$ (Yam) $v$ Central Criminal Court [2014] EWHC 3558 (Admin), [79].

${ }^{64}$ Sir Jack I H Jacob, The Fabric of English Civil Justice (Sweet \& Maxwell 1987) 60.

${ }^{65}$ I H Jacob, 'The Inherent Jurisdiction of the Court' (1970) 23 Current Legal Problems 23, 25.
} 
Notwithstanding these continuities and the picture which emerges of two parallel and analogous procedural mechanisms, the implicit conflation of the two phenomena implied both by Ouseley J's reference, in the context of an in camera order, to a 'PII certificate', as well as the earlier use in the Amin litigation of the same phrase, must be resisted. First of all, the vocabulary of PII is sufficiently well-established in reference to the specific phenomenon of material's non-disclosure in evidence that its transplantation to the context of in camera trials to obscures more than it illuminates, potentially obstructing a sufficiently granular treatment of the issues. But further, as this sections considers, the continuity between the two procedural mechanisms must be balanced against a series of distinctions between them which ultimately demonstrate the necessity of keeping them analytically separate. These distinctions relate both to the form of non-disclosure to which each of the mechanisms gives effect and to their differing relationship with constitutional principle.

On this first point - the different forms of non-disclosure at issue - it is clear that to treat the different procedural mechanisms as parallel phenomena brings into focus the manner in which the law responds to the fact that what exactly the public interest will require (in terms of information being withheld from public view) might vary according to the nature of the material or information in question and the specific basis of its sensitivity. It does so by implementing a form of 'price discrimination' as regards the level of secrecy which applies to given material. The point can be made as follows: once it is seen that both PII and in camera orders are available, it may not be immediately clear why prosecuting authorities would ever wish to claim the former: the in camera hearing and associated reporting restrictions evidenced by the cases described above would seem to do all of the work done by PII in preventing the material from becoming known to the public but, crucially, without preventing it from being put before and relied upon by the court. That is, as compared to PII, in camera orders allow the prosecution to eat its cake 
and yet still have it, never having to choose between bringing the prosecution and disclosing the material whose disclosure is incompatible with the public interest.

But this differentiation in the level and form of (non-)disclosure associated with each mechanism reflects the fact that there may exist (at least) two categories of sensitive material - one of which, compatibly with the public interest, can be put before the court and the defendant but not the public (and so can, compatibly with the public interest, be aired in camera but only in camera) and another which the public interest requires is kept also from the defendant (and whose nondisclosure would not render the trial unfair or impossible). The availability of PII, that is, would serve to deal with material which is of even greater sensitivity than that which justifies the making of an in camera order, or whose sensitivity is of such a nature as to render it unsuitable for disclosure even to the defendant. An example may be information about the source of police intelligence, disclosure of which to the defendants in a criminal trial would potentially put human informants or future intelligence at risk, and which is as such the frequent basis of claims for PII. It is highly unlikely that such information could be disclosed even as part of in camera proceedings: though this would allow use of it to be made use the courts without going so far as to disclose it to the public at large, the precise nature of its sensitivity is such that even this limited disclosure would be contrary to the public interest. This can be contrasted with material which, though its dissemination to the public at large is considered to be contrary to the public interest, is already known to the defendants - possibly because, as was the case in both Wang Yam and Incedal, it forms part of the defence which they wish to offer to the charges faced. In that case not only would the material's exclusion be in direct tension with constitutional principle (see next section) but it would in fact be wholly illogical.

This logic of differential sensitivity - and the consequent need to have available a multiplicity of mechanisms capable of reflecting the difference in question - is of particular importance in the 
context of material whose disclosure to the public interest would be contrary to the public interest but whose disclosure is a necessary element of the fairness of the trial process (a point discussed further in the next section). Were PII the sole available mechanism by which the public interest might be protected against disclosure, the prosecution would be faced with an unenviable dilemma: either to risk (what it believes to be) harm to the public interest by ceding to the disclosure of the material in question in order to ensure the fairness of the trial, or to insist upon the public interest in non-disclosure and abandon the prosecution. The availability of the in camera order neatly evades the dilemma: the material can be used but without being disclosed to the public at large, ensuring that neither does an unfairness result nor is the public interest harmed by the cessation of a prosecution which would otherwise take place. Prosecution will be impossible only where the material in question cannot be disclosed even to the defendants or where the making of an in camera order would itself be contrary to constitutional principle.

As this sketch demonstrates, there is a compelling internal logic to the coexistence of the two procedural mechanisms - PII and the in camera order - within the courts' arsenal, where they are available to be drawn - and combined - on as necessary according to the nature and extent of the sensitivity of the material whose disclosure would harm the public interest. And it need not be thought that these two methods of exercising the inherent jurisdiction with a view to protecting the public interest against disclosure exhaust the possibility: were another permutation of disclosure and non-disclosure asked of the court, some other procedural mechanism might, the account offered here suggests, be employed if to do so were possible from the point of view of the constitutional principle to which we now turn. If the category of procedural mechanisms which employ the courts' inherent jurisdiction to protect the public interest is not closed then there is further reason for desiring that the limiting rules arising out of the context of PII are transposed, as far as is possible, to novel exercises of that jurisdiction. 


\section{PII, 'secret trials', and constitutional principle}

That the two mechanisms respond to variations in the sensitivity of material with different degrees of (non-)disclosure is relevant also to their relationship with the constitutional principles which structure the courts' ability to innovate procedurally. The first relevant constitutional principle is that of open justice, which has been glossed in a leading recent Supreme Court decision as requiring that "judicial processes should be open to public scrutiny unless and to the that there are valid countervailing reasons." ${ }^{96}$ It is necessary to insist however, that the principle itself is captured by the first half of this definition: where there are valid countervailing reasons, we are dealing with a justified interference with or departure from the constitutional principle, but the interference or departure is no less real because justified. The courts seem - though without great clarity - to have taken that view that PII is not per se a breach of open justice. In Al Rawi v Security Services, Lord Dyson noted that the PII process has evolved to permit the use special advocates and that "[t]here can be no objections to the use of special advocates for that purpose, since the PII process fully respects the principles of open justice and natural justice". ${ }^{67}$ There is perhaps an ambiguity in Lord Dyson's words - is he referring to the process by which a decision on whether the public interest in non-disclosure outweighs than in disclosure or the fact of non-disclosure itself? Either way, it seems true that on the definition of open justice quoted above, PII is indeed compatible with it: it does not result in the publication of closed judgments (unlike CMP) nor in the exclusion of press and public from the litigation process. In camera trials, however, by definition imply the exclusion of the press and public and so involve a departure from the principle of open justice, one which has been readily acknowledged by the courts who have ordered them to take place. ${ }^{68}$

\footnotetext{
${ }^{66}$ Kennedy v The Charity Commission [2014] UKSC 20, [110]. On open justice generally, see most famously, Scott v Scott [1913] AC 417.

${ }^{67}$ Al Rawi [2011] UKSC 34, [49].

${ }^{68}$ Incedal [2014] EWCA Crim 1861, [12].
} 
The consequence of this distinction is that the threshold for the making of an in camera order is, the case law shows, higher than that which applies to a claim for PII, in which material is not disclosed in proceedings which nevertheless remain open to the public. The difference is this: though PII can be successfully claimed wherever the public interest in disclosure is outweighed by that in non-disclosure (assuming that the fairness of a trial is not prejudiced by the nondisclosure of the material in question), ${ }^{69}$ an in camera order will be made only where to not do so would put at risk the administration of justice by, for example, "deterring the Crown from prosecuting a case where it otherwise should do so". ${ }^{70}$ Unlike the non-disclosure of material in evidence, that is, an in camera order is inherently incompatible with constitutional principle (specifically, that of open justice) and so such orders, unlike PII, requires that some supervening constitutional principle (here, the principle "that the paramount object of the Court is to do justice") $)^{71}$ be at stake if they are to be made. ${ }^{72}$ The same will be true of any other exercise of the inherent jurisdiction similarly calculated to protect the public interest against harm caused by the disclosure of sensitive material: the threshold at which it becomes possible is a function of its relationship with constitutional principle. Where constitutional principle is not at stake the only question as to how the inherent jurisdiction might be put to work seems to be that of where the balance of the public interest lies. Where, instead, constitutional principles are at stake, the courts appear to fall back upon a loose hierarchy of such principles within which open justice is subordinate to a wider duty to do justice and to which it will therefore give way if necessary.

Constitutional principle speaks not only to the circumstances under which a given procedural mechanism can be put to use - what we might call its triggering conditions - but also to the

\footnotetext{
${ }^{69} \mathrm{R} v \mathrm{H}$ [2004] UKHL 3, [36].

${ }^{70}$ Incedal [2014] EWCA Crim 1861, [17].

${ }^{71}$ Incedal [2014] EWCA Crim 1861, [17].

${ }^{72}$ See also In re K [1965] AC 201, 238: "a principle of judicial inquiry, whether fundamental or not, is only a means to an end. If it can be shown in any particular class of case that the observance of a principle of this sort does not serve the ends of justice, it must be dismissed; otherwise it would become the master instead of the service of justice." (Lord Devlin).
} 
limits upon the steps which might be taken to protect the public interest, which can now be seen to be those which exist upon the inherent jurisdiction generally. The example of CMP - which, in undoing the equality of arms which would normally exist as between the parties, represents a departure not merely from open justice but also from natural justice - shows, for example, that particular mechanisms' relationship to constitutional principle may be such as to prevent their employment except where Parliament has legislated to permit it, as is has with CMP. ${ }^{73}$ The principle of natural justice outranks that of open justice within the hierarchy of constitutional principle and cannot be departed from even where to do so would be necessary to do justice. Or, perhaps more logically, the requirement to adhere to the principle of natural justice is but one facet of the overarching requirement that justice be done, and so it is a contradiction in terms to talk of departing from that principles in order to do justice. That neither PII nor in camera trials of the sort at issue here are inherently incompatible with the dictates of natural justice is reflected in the fact that in neither case do the courts look for statutory authority before giving effect to them; such authority being the only thing to which the duty to do justice gives way.

This does not mean, however, that the two procedural mechanisms under discussion will always and everywhere be compatible with natural justice. On the contrary, the case law demonstrates that if their use will result in a trial being unfair the courts will not permit it. In relation to PII and the consequent non-disclosure of sensitive material in evidence, we have already noted Lord Bingham's elaboration in the leading case on PII in criminal trials of the principle that, if the effect of non-disclosure would be to render the trial unfair "fuller disclosure should be ordered even if this leads or may lead the prosecution to discontinue the proceedings so as to avoid having to make disclosure." ${ }^{74}$ We see an awareness of the same contingent possibility of unfairness - and the necessity of avoiding it - in the emerging jurisprudence governing in camera

\footnotetext{
${ }^{73}$ See the Justice and Security Act 2013.

${ }^{74} \mathrm{R} v \mathrm{H}$ [2004] UKHL 3. [36].
} 
orders. In Wang Yam the Court of Appeal notes that Ousely J, who made the original such order, had "made plain" that "the interests of justice could never justify excluding the press and the public if the consequence would be that the trial would not be fair." ${ }^{75}$ Fairness acts as a limit upon the exercise of the inherent jurisdiction and, though the case law does not directly equate the two concepts, the best understanding must be that is that these remarks are simply an instantiation of the same constitutional concerns which underlie the decision in $\mathrm{Al} \mathrm{Rawi.{ } ^ { 7 6 }}$ This adds context to the Court of Appeal's expression in Incedal of 'grave concern' about the cumulative effect of holding a criminal trial in camera and anonymising the defendants (as per the original order). ${ }^{77}$ Though the Court of Appeal expresses that concern in the language of justification ("[w]e find it difficult to conceive of a situation where both departures from open justice will be justified") ${ }^{78}$ it might be argued instead to be the case that the cumulative effect of the two departures from open justice, neither of which itself necessarily gives rise to unfairness, is a necessary rather than merely contingent incompatibility with natural justice. That is, even it were justified by the circumstances in which non-disclosure is sought, it would not represent a permissible use of the inherent jurisdiction. For present purposes, the point is this: unlike CMP, PII and in camera orders are not inherently contrary to natural justice (unfair) but if their use in specific contexts or in specific ways would be so, they cannot take place on the basis of the inherent jurisdiction alone but would require statutory authority. In another reflection of the Parliamentary supremacy which permits primary legislation to breach the rules of natural justice,

\footnotetext{
${ }^{75} \mathrm{R} v$ Wang Yam [2008] EWCA Crim 269, [6]. As made explicit in Wang Yam, this rule implies that the holding of an in camera trial is not ipso facto unfair. For present purposes, I take that understanding to be correct. 76 Al Rawi [2011] UKSC 34.

77 Incedal [2014] EWCA Crim 1861, [47].

78 Incedal [2014] EWCA Crim 1861, [47].
} 
statutory rules similarly limit the exercise of the courts' inherent jurisdiction. ${ }^{79}$ So too do the provisions of the Civil Procedure Rules. ${ }^{80}$

\section{Conclusion}

This piece has explored the ways in which the courts use their inherent jurisdiction to regulate their own proceedings in order to protect the public interest against harm which would result from information being disclosed as part of the trial process. It has demonstrated the commonalities which exist between, on the one hand, the law of public interest immunity and, on the other, that of in camera trials and argued that by insisting upon these commonalities treating the two mechanisms as parallel - we begin to see how the courts should address as yet unasked questions about the ordering of 'secret trials'. That is, the possibility is opened up of transposing the well-developed and relatively robust body of principles which govern the use of the orthodox variant of PII into the brave new world of in camera trials. Such a development would be particularly appealing given that the form of secrecy at issue in the in camera cases is democratically obnoxious in a way which traditional PII need not be. Moreover, the differences between PII and in camera trials shed light upon the constitutional principles which regulate (and limit) their use - the question of what are the fundamental values which characterise the UK's constitutional order and how those values interact with each other. The picture which emerges is of a constitution more tolerant of departures from open justice than one might have expected, but in which (one understanding of) justice continues to sit at the apex. As the demand for in

\footnotetext{
$79 \mathrm{Jacob}$ (n 65) 24. It may be the case that the statutory provision in question ousts the inherent jurisdiction even if not explicit: M S Dockray, 'The Inherent Jurisdiction to Regulate Civil Proceedings' (1997) 113 Law Quarterly Review 120, 127-8.

${ }^{80}$ Dockray (n 79) 128 states that "the inherent jurisdiction may supplement but cannot be used to lay down procedure which is contrary to or inconsistent with a valid rule of the Supreme Court". This was approved by the Court of Appeal in Raja v Van Hoogstraaten (No 9) [2008] EWCA Civ 1444; [2009] 1 WLR 1143 where it was stated that the position "pre-CPR... was that the inherent powers of the court could not be invoked to do something which was inconsistent with a rule" and confirmed that "[t]he same position has obtained since the introduction of the CPR" (at [74]-[78]).
} 
camera trials grows, one can expect these values to come under further, and more sustained, pressure. 